In fact, the body is a machine of the nature of an army, not of that of a watch, or of a hydraulic apparatus. Of this army, each cell is a soldier, an organ a brigade, the central nervous system head-quarters and field telegraph, the alimentary and circulatory system the commissariat. Losses are made good by recruits born in camp, and the life of the individual is a campaign, conducted successfully for a number of years, but with certain defeat in the long run.

The efficacy of an army, at any given moment, depends on the health of the individual soldier, and on the perfection of the machinery by which he is led and brought into action at the proper time; and, therefore, if the analogy holds good, there can be only two kinds of diseases, the one dependent on abnormal states of the physiological units, the other on perturbation of their co-ordinating and alimentative machinery.

Hence, the establishment of the cell theory, in normal biology, was swiftly followed by a "cellular pathology," as its logical counterpart. I need not remind you how great an instrument of investigation, this doctrine has proved in the hands of the man of genius, to whom its development is due; and who would probably be the last to forget that abnormal conditions of the co-ordinative and distributive machinery of the body are no less important factors of disease.

Henceforward, as it appears to me, the connection of medicine with the biological sciences is clearly defined. Pure pathology is that branch of biology which defines the particular perturbation of cell life, or of the co-ordinating machinery, or of both, on which the phenomena of disease depend.

Those who are conversant with the present state of biology will hardly hesitate to admit that the conception of the life of one of the higher animals as the summation of the lives of a cell aggregate, brought into harmonious action by a co-ordinative machinery formed by some of these cells, constitutes a permanent acquisition of physiological science. But the last form of the battle between the animistic and the physical views of life is seen in the contention whether the physical analysis of vital phenomena can be carried beyond this point or not.

There are some to whom living protoplasm is a substance even such as Harvey conceived the blood to be, "summâ cum providentiâ et intellectu in finem certum agens, quasi ratiocinio quodam "; and who look, with as little favour as Bichat did, upon any attempt to apply the principles and the methods of physics and chemistry to the investigation of the vital processes of grcwth, metabolism, and contractility. They stand upon the ancient ways; only, in accordance with that progress towards democracy which a great political writer has declared to be the fatal characteristic of modern times, they substitute a republic formed by a few billion of "animula" for the monarchy of the all pervading " anima."

Others, on the contrary, supported by a robust faith in the universal applicability of the principles laid down by Descartes, and seeing that the actions called "vital" are, so far as we have any means of knowing, nothing but changes of place of particles of matter, look to molecular physics to achieve the analysis of the living protoplasm itself into a molecular mechanism. If there is any truth in the received doctrines of physics, that contrast between living and inert matter, on which Bichat lays so much stress, does not exist. In nature, nothing is at rest, nothing is amorphous; the simplest particle of that which men in their blindness are pleared to call "brute matter" is a vast aggregate of molecular mechanisms, performing complicated movements of immense rapidity and sensitively adjusting themselves to every change in the surrounding world. Living matter differs from other matter in degree and not in kind; the microcosm repeats the macrocosm; and one chain of causation con nects the nebulous original of suns and planetary systems with the protoplasmic foundation of life and organisation.

From this point of view, pathology is the analogue of the theory of pertarbations in astronomy; and therapeutics resolves itself into the discovery of the means by which a system of forces competent to eliminate any given perturbation may be introduced into the economy. And, as pathology bases itself upon normal physiology, so therapeutics rests upon pharmacology; which is, strictly speaking, a part of the great biological topic of the influence of conditions on the living organism and has no scientific foundation apart from physiology.

It appears to me that there is no more hopeful indication of the progress of medicine towards the ideal of Descartes than is to be derived from a comparison of the state of pharmacology, at the present day, with that which existed forty years ago.
If we consider the knowledge positively acquired, in this short time, of the modus operandi of urari, of atropia, of physostigmin, of veratria, of casca, of strychnia, of bromide of potassium, of phosphorus, there can surely be no ground for doubting that, sooner or later, the pharmacologist will supply the physician with the means of affecting, in any desired sense, the functions of any physiological element of the body. It will, in short, become possible to introduce into the economy a molecular mechanism which, like a very cunningly contrived torpedo, shall find its way to some particular group of living elements, and cause an explosion among them, leaving the rest untouched.

The search for the explanation of diseased states in modified cell life ; the discovery of the important part played by parasitic organisms in the ætiology of disease; the elucidation of the action of medicaments by the methods and the data of experimental physiology; appear to me to be the greatest steps which have ever been made towards the establishment of medicine on a scientific basis. I need hardly say they could not have been made except for the advance of normal biology.

There can be no question then as to the nature or the value of the connection between medicine and the biological sciences. There can be no doubt that the future of Pathology and of Therapeutics, and therefore that of Practical Medicine, depend upon the extent to which those who occupy themselves with these subjects are trained in the methods and impregnated with the fundamental truths of Biology.

And, in conclusion, I venture to suggest that the collective sagacity of this Congress could occupy itself with no more important question than with this : How is medical education to be arranged, so that, without entangling the student in those details of the systematist which are valueless to him, he may be enabled to obtain a firm grasp of the great truths respecting animal and vegetable life, without which, notwithstanding all the progress of scientific medicine, he will still find himself an empiric?

\section{ON THE VALUE OF PATHOLOGICAL EXPERIMENTS ${ }^{1}$}

$A S$ reporter on Medical Education at the last International Medical Congress held in Amsterdam, I raised the question how far the experimental method is necessary to instruction; and the result at which I arrived was that the use of this method to its greatest extent, and especially of vivisection, is an indispensable means. ${ }^{2}$ In a still higher measure, however, I had to raise into prominence the importance of this method in research ; and, in opposition to those who, with constantly increasing vehemence, brought accusations against the experimental investigators on account of the direction and method of their researches, I was able to say, with the lively assent of the numerous members of the Congress, and without one word in contradiction: "All those who attack vivisection as a means of science have not the least idea of the importance of the science, and much less of the importance of this aid to knowledge."

In the two years which have since passed away, the agitation of the opponents has grown both extensive and important in its object. One country after another has been drawn into their net, and international combinations have been formed, in order by united force to obtain greater results. No increase of satisfaction has been produced by the concessions made in 1876 by the legislation in England. The demands have increased: a petition from the new Leipsic Society for the Protection of Animals, dated March 8 of the present year, desired of the German Reichstag the enactment of a law by which "cruelty to animals under the pretext of scientific research" should be punished "with imprisonment for periods of not less than five weeks to two years, and with simultaneous deprivation of civil rights." All, indeed, do not go so far. Many do not demand that all experiments on living animals should be at once suppressed, but that there should be limitations, some demanding more, others less. But even these do not make it secret that this concession is only provisional; and they demand that even the official laboratories of the universities should be placed under

Address given at the International Medical Congress by Rudolf Virchow, Medical Four in the University of Berlin. The Editor of the British Virchow's address.

${ }^{2}$ Congrès Périodique International des Sciences Médicales, 6 Session, Amsterdam (1879), r880, p. ז46, Archiv fil Pathol. Anat., Band lxxxy, Heft 3 . 
the control of the members of the Society for the Protection of Animals, so that the members may be at liberty to enter the laboratories at any time.

It would be a mischievous delusion to believe that this movement is without prospect of success, and devoid of danger because of its manifest exaggeration. On the contrary, unmistakable signs indicate that it has gained powerful allies, and that there is an increasingly impending danger in many countries that even the State institutions, created expressly for the purpose of experiment, may have the scientific freedom. of their methods attacked. So much the more does it seem to be incumbent on the representatives of medical science to defend their position, and to meet international attacks by international weapons. The most powerful weapon, however, is truth; and here, above all, truth founded on competent knowledge. If we cannot demonstrate our good right before all the world, and come to a mutual agreement on the ground of this right, our cause must henceforth be looked on as a lost one.

The attacks which are directed against us fall, when closely examined, into two categories, according to the principal point. On the one side it is alleged that the experimental method-yea, modern medicine altogether-is materialistic, if not nihilistic, in its ultimate object; that it offends against sentiment, against morals. On the other side it is denied that the introduction of experiments on animals has had any actual use, that medicine has been really promoted thereby, and especially that the cure of diseases has in consequence made any recognisable progress. Even those who admit that there has been some progress, yet believe that just as much information could have been imparted by anatomy alone as by experiments on living animals.

Such objections are not new to one who knows the history of medicine. For hundreds of years, on similar or identical grounds, the dissection of human bodies was impeded, and anatomist were confined to the dissection of dead animals ; if, indeed-as was done by Paracelsus, the contemporary of Vesalius-the insulting question were not asked, whether anatomy was of any use at all. The feeling of the masses was raised against the dissection of human bodies; and it is known that, at the commencement of the fourteenth century, the church for the first time gave permission for this to be done, but only under limita tions which were still greater than those under which the larger number of our modern opponents would permit vivisection. I was no accident that the period of the reformation in the church first created for the great Vesalius a free field, so that he might test the truth of Galen's traditional dogmata by his own investigation of human bodies, and place true human anatomy in the stead of that anatomy of animals, which had during centuries formed the groundwork of all medical ideas on the internal arrangement of man.

And now, first of all, pathological anatomy-what obstacles it has had to overcome even in the present time! Nothing is more instructive in this respect than the narrative which Wepfer, the celebrated discoverer of the hæmorrhagic nature of ordinary apoplexy, gives of the acts of enmity with which he was persecuted when-it was towards the middle of the seventeenth century-the council of the town of Schaffhausen had allowed him to dissect the bodies of those dying in the hospital. The only reply which he made to those who said to him that it is injurious and disgraceful to soil his hands with blood and sanies, was, that he could cleanse his hands with some water; but that much more disgraceful and injurious is ignorance of anatomical facts, which inflicts on inexperienced physicians and surgeons a disgrace that not the Rhine, not the ocean itself can wash away. Hence the study of anatomy is much rather to be praised, and to be supported by those who exercise the executive power in the State.

In fact, one Government after another has recognised the decided importance of anatomical science. As far as the civilised world extends, so far at the present day are human bodie dissected. Even the laity comprehends that, without the most accurate knowledge of the structure of the human body and of the changes which disease and recovery produce in it, skilled action on the part of the physician is impossible. Any one who can only take a general survey of the history of science, must know that both the greatest epochs of the resuscitation and reformation of medicine commenced with the definite establishment of both the principal branches of human anatomy, and

t Joh. Jac. Wepfer. "Observ. Anat. ex Cadaveribus eorum quos sustulit Apoplexia." Schaff hausii 1658 . "Præfatio: Turpior et damnosior rerum ana tomicarum ignorantia est, qua imperitis Medicis et Chirurgis ignominiam parit, quam nec Rhenus, vec Oceanus abluere potest." were even essentially brought about thereby. In the sixteenth century it was physiological anatomy which brought about the definitive victory of empiricism over dogmatism, of science over tradition; in the eighteenth century it was pathological anatomy which replaced mysticism by realism, speculation by necropsy, obscure groping and guessing by systematic thought. The opponents indeed spoke of materialism ; but Harvey has rightly said : "Sicut sanorum et boni habitas corporum dissectio plurimum ad philosophiam et rectam physiologiam facet, ita corporum morbosorum et cacheticorum inspectio potissimum ad pathologiam philosophicam. ${ }^{1}$

Antiquity had only one time in which a powerful effort was made for the independent develop nent of human anatomy. It was the time of the Alexandrian School, in the third century B.C., when Erasistratus and his companions, under the protection of the Ptolemies, undertook the first regular dissections of human bodies. The school existed only a short time, and yet it caused the first perceptible agitation of the humoral system of pathology. With the more accurate knowledge of the arrangement of the nerves there grew up a new and more powerful generation of solidists ; the empirics raised themselves against the dogmatists, and, though again soon enough subdued, they left behind them as a lasting inheritance the consideration that there is a certain limit to human piety, that the right of the individual to the preservation of the integrity of his body is interrupted by death, and that the veil which covers the mystery of life cannot be raised without the forcible destruction of the connection of the several parts of the body. It is this thought which, as finally realised, has brought forth modern medicine. But, eighteen centuries after the Alexandrian School, the impress of the humoral system of pathology still held independent sway in medicine. Of any positive progress in pathology during that long period nothing can be said. For Bacon has excellently said, in his " Novum Organum," "Quæe in Naturâ fundata sunt, crescunt et augentur: quæ autem in opinione, variantur, non augentur." The old humoral pathology was incapable of development, because it was not founded on nature, but on dogmata. From however different origins they had sprung, Galenism combined everywhere with orthodoxy: among the Arabians with Islam, in the we t with Christianity ; and it required the powerful movement of the Reformation to burst the chains within which antiquated custom and hierarchical schooling had fettered the thoughts even of physicians. From Erasistratus to Vesalius, and at last to Morgagni, is such an immense stride that it cannot remain concealed even from the weakest eye. Not only the outer form, but the whole nature of medicine has been thereby changed. If one follows Vesalius, yea, even Morgagni, in speaking of the humoral pathology as among still-existing things; if I myself am yet obliged to contend against Rokitansky, the last of the pronounced humoral pathologists, it must still not be forgotten that that was no longer the humoral pathology of Galen or Hippocrates. The four "cardinal juices" Paracelsus had already buried; modern medicine recognises only the actual juices which flow in the vessels, and thence penetrate into the tissues. This modern humoral pathology was essentially bloodpathology (hæmatopathology). In name only does it agree with the humoral pathology of the ancients : in reality, it is quite another thing.

But even hæmatopathology is now happily overcome, and indeed, again, through a proper direction of anatomical study. Since the first but very uncertain researches in the territory of so-called general or philosophical anatomy which Bichat began in the commencement of the present century, down to the more and more rapid advances which the present time has made by means of the microscope, in the knowledge of the more minute processes of healthy and diseased life, attention has been constantly more and more turned from the coarser relations of whole regions and organs of the body to the tissues of which those organs are constituted, and to the elements which again are the efficient centres of activity within those tissues. Immediately after Schwann had demonstrated the importance of cells in the development of the tissues, Johannes Müller and John Goodsir made the happiest applications of the new view to pathological processes ; and, looking back to a period in which we ourselves have lived, and which embraces little more than a generation of man, we may now say that never before was there a time when a similarly great zeal in research, and a comparable-though only approximately so-progress in science and knowledge, has

"Guil. Harveji Exercit. Anat." ii., "De Motu Cordis et Sanguinis Circulatione," Roterodami, 167 ז, p. 174 . 
spread among physicians. The multiplication of the powers of labaur, the constantly increasing emulation in researches, the unmistakable increase in the depth of the questions proposedall these are phenomena of the most gratifying nature; and one would be very ungrateful if he would not acknowledge that these were in a considerable measure to be ascribed to the improvements in the means of instruction and to the multiplication of laboratories.

No one can be more disposed to concede the high value of anatamical studies to the development of medicine, than one who has made it a part of the task of his life to place anatomy and histology in that commanding position in the recognition of his contemporaries which they deserve. Nothing lies further from me than to discourage those who still expect the greatest benefit to the practice of medicine to arise from following out these studies. May indeed the growing youth, who will have to follow us in a suring the progress of medicine, learn from our example how useful it is to lay the true foundation of our science in anatomy. Assuredly much of that which remains dark to us will then be rendered clear.

But we must not allow ourselves to be forced back on his way as the only permissible one. Were the attempt to hinder totally or in great part researches on living animals to become successful, the same procedure which has been now entered on against vivisection would also be commenced against mortisection. There would no longer be societies for the protection of animals, which we see opposed to us, but societies for the pro. kection of human bodies. There would no longer be thunderings against the tormentings of animals, but against the desecration of corpses. Under the standard of humanity, which is just now unfurled even for animals, there would be preached in a still more impressive manner the campaign against the barbarity of medical men. People would appeal to the feeling of the masses-to the mother on behalf of the body of her child, the son on behalf of the dear remains of his parents. It would be proved that the dismembering of human bodies is injurious to morals and opposed to Christianity. It would be shown that the anatomy of man is useless for the treatment of disease; and perhaps there would be found ignorant or timid or egotistical medical men who would come forth as witnesses against science. The mildest of our opponents would perhaps propose to us the compromise that we should again make the dissection of animals the foundation of instruction. In short, we should be thrown back to the time before Mondini, before Erasistratus.

Such thoughts are by no means the productions of an alarmed fancy. The tudy of history teaches us sufficiently that victorious fanaticism knows no limits. It desires to heap to the full the measure of its victories; and, even when the traders are contented, the irritated masses pre:s on to obtain the whole results. It is indeed not at all necessary for us to go back to antiquity in order to bring before our eyes the condition of such minds. In no country of modern time are there wanting examples which are recognisable by the eye ; for, along with the societies against "scientific tormentors of animals," there exist everywhere, but mostly in a more unassuming form, brotherboods and associa. tions of all kinds which labour most zealously against the scientific examination of dead bodies. It needs only an impassioned and exciting agitation, such as is now going on against the "turture chambers of science," to denounce to popular indignation the dissecting-rooms as places where the youths under instruction are made barbarous. Whoever undertakes, with the same extravagant fancy as is now u-ed in delineating the physio logical laborat $\lrcorner$ ry, to de cribe the post-mortem examination of a man, or an anatomical theatre, will not fail to have readers who will turn away with horror and amazement at the misdeeds of anatomists.

In vain will an appeal be made to the fact that not one single school of medicine has existed which has, without a fundamental knowledye of anatomy, established lasting advances in the science or the art of healing. The homoopaths and the socalled nature-doctors (Naturärzte), who indeed are already on the scene to strengthen the ranks of the anti vivisectors, will step forth and praise their results. Scepticism, which, from time to time grasps about even in medical circles, and which only too easily fuids there followers who have in yain called on medical aid for themselves or their belongings-it will scornfully point out how often the physician is powerless against disease. Therapeutics will be thrown aside as useless lumber; and it will be pointed out to us, as is now already done in the petitions of the sacieties for the protection of animals, that therapy is to be replaced by hygiene, the treatment of individual pritients by general measures of public sanitation. And the attempt will then be made to excite the belief that prophylaxis can exist without anatomy or experiments on animals.

In so large an assembly of medical men as this is, a glance at those present teaches in how many special directions the mectioine of to day has gone. Not every ome of these directions is in like measure and as constantly in want of all the means of inquiry and scientific preparation, which are indispensable to cure disease as a whole. Hence, from time to time, a perceptible onesidedness becomes manifest in certain of these special arrangements. One believes in his own sufficiency, and looks with indifference, sometimes with a kind of polite contempt, on the rest of medicine. Even the traly scientific studies are not exexnpt from such one-sidedness; on the contrary, human pride, the tendency to over-estimation of orreself, prevail more readily in these than in partial disciplines. We ourelves have seen that organic chemi try, by a most partial use of a very moderate store of knowledge, has made the attempt-and indeed not without some temporary resnlt - to prescribe its laws to medicire: and that numerous practical physicians, unmindful of the history of our science, have in fact sought safety in a new kind of iatrochemistry. Yes, I have a very lively remembrance of the fact that, when I myself was entering on the scientific caseer, the hope of giving a purely physical aspect to biology was so powerful, that every attempt at morphological study was treated as something antiquated.

We have not allowed ourselves to be prevented by this from carrying on anatomical research with every exertion; and we are now in the happy position of seeing it everywhere acknowledged, that every advance in minute anatomy sees behind it an advance in physiolugical knowledge. Physiologists themselves are more and more becoming al o histologists. No one however nust say that physiology is becoming totally dissolved in histology. No attempt must be made to replace one special subject by another. What is necessary to all branches of medical science in general is the knowledge of life. But this can as little be attained by a simple external examination of the livin $s$ as by a partial investigation of the dead. It can be reached by no single study or specialty; it is much rather the collective result of the cultivation of all individual branches of science.

What is to be attained by a mere external examination of the living body has been thor ughly taught by the alder medicine. For centuries sick and healthy have been observed with assiduous diligence, and in fact most valuable material has been collected in the most ingenious nanner; but, on the whole, no advance has been made beyond "symptoms." What was perceived were the signs of something internal which was not perceived-indeed the possible perception of which was hitherto doubted. Life itself stood as it were outside observation; it was only a subject of speculation. Intellectual formulæ were laid down, spiritual. istic or materialistic, according to the general tendency of the mind of the individual or of the time; but all agreed in the conviction, that life itself is a transcendental and metaphysical problem. For the practical physician, snowledge that was founded in fact began with symptomatology; for disease as strch was apparently not less tranєcendental than life itse f, whose antitype it constituted.

How has it now come to pass, that symptomatology has entirely lost the high position in which it still stood little less than a generation ago, to such an extent that in most universities it is no more taught as a specialty? Have symptoms no more any importance for the physician? Can a diagnosis be made without a knowledge of symptoms? Certainly not. But, for the scientific physician, the symptoms are no more the expression of a hidden power, recognisable only in its outer workings: he searches for this power itself, and endeavours to find where it is seated, in the hope of exploring even the nature of its seat. Hence, the first question of the ipathologist and of the biologist in general is, Where? That is the anatomical question. No matter whether we endeavour to ascertain the place of the disease or of life with the anatomical knife, or only with the eye or the hand; whether we dissect or only obserwe, the mathad of investigation is always anatomical. For this reason, the thoroughly logical founder of pathological anatomy med his fundamental brok "De Sedibus Morbornm"; and hence this book became the starting-point of a movement which, in a few decades, has changed the entire aspect of science.

This change has been carried out to the greatest extent in ophthalmic surgery. Who could limit himself to perceiving 
that modern ophthalmology has scarcely a single point of similarity with that of the last century? Who contents himself with the symptom of amaurosis? Who despairs of recognising in it the existence of glaucoma? Every ophthalmic surgeon has in his hands the means of studying the thing itself, and not merely its signs. Even the anti-vivisectors acknowledge that ophthalmology is a study that is capable of effecting something. But they forget that every organ of the body is not so favourably placed and arranged for the observation of its inner processes as is the eyeball. Since the wonderful discovery of the ophthalmoscope, anatonical analysis, even without the use of the knife, has become capable of penetrating so far into the individually remote, that we can immediately observe and study by themselves the smallest features of the fundus oculi, even, indeed, its single cells, or groups of cells, just as in an artificial preparation of an eye that has been excised. But it mu.t not be forgotten that long anatomical and physiological studies have been a necessary preliminary to the interpretation of that which is now so easily perceived. The structure, arrangement, and function of each single part had first to be laboriously established before it was possible, by a transitory glance at the altered tissue, to recognise what is especially changed; and no medical man will attain to a true comprehension of the essence of these changes if he have not previously learned to recognise most accurately the anatomical and physiological nature and the possible pathological changes of the individual constituent parts of the eye.

They speak lightly who object to us, that not all the branches of medicine stand on the same height with ophthalmology. That will never be the case. Just as it is easier to explore the sea in its depths than the solid land, so will the most transparent organ of the body always be the most convenient place for medical diagnosis and treatment. While it is possible to observe without difficulty a cysticercus in the hinder part of the retina, one will always be taught to bring a cysticercus of muscle or a trichina in a patient to light by vivisection. Never can it be required that every medical specialty should altogether equal ophthalmology in security of treatment and diagnosis; but any measure of success can only be sought in the use of the ophthalmological methud in a corresponding manner in the other special departments. This method, however, is anatomical, or, as it has otherwise been expressed, localising.

With this, we have reached the point which denotes the boundary between ancient and mode $\mathrm{n}$ medicine. The principle of modern medicine is localisation. To those who still constantly ask of what use modern science has been to practical medicine, we can simply point out that every branch of medical practice has accommodated itself to the principle of localisation, not only in pathology, but also in therapeutics, and that thereby the greatest benefit has accrued to the sick. It is quite superfluous to seek out single examples in order to show what profit the new knowledge has brought. Such examples are abundant. But we do not require them, for we can point to the general character of modern medicine. All those studies which already at an earlier period had a natural tendency to localisation, such as special surgery and dermatology, have in this way been raised to their present state of perfection. Those, however, which have retained from the old humoral pathology a tendency to the establishment of generalising formula gradually renounce the favourite tradition ; and the fact is more and more comprehended, that generalis:tion in truth is nothing else than multiplication of foci, and that the cure of a so-called general disease signifies just as much as the eradication of a single focus. That was in fact a reform in head and limbs; and he who has not grasped it ought not to say that he has consciously followed the progress of seience.

The nation of the general validity of the doctrine of the localisation of disease and of the multiplication of foci of disease in the same individual, stands, as was often objected to me in the beginning of my career as a teacher, in strict opposition to the idea of the wnity of disease, or, as it is expressed in customary language, to the ens morbi. My former colleagues still retained large portions of this idea; they believed that the practical physician entered into arbitrary, and therefore dangerous, speculations, when, in the presence of a single case of disease, he ascumed the disease to be a plurality. To me it seems rather the reverse; that the physician enters on a fruitless project (schematismus), and one dangerous to his patients, if he suppose each individual case of disease to correspond to the opirion of his school or his own private view, and calculate his prognosis and treatment thereby. Meanwhile, these considerations, derived from medical practice, on the utility of a certain way of perceiving disease, can lead to no decision as to its truth, and yet, at this result only is it possible to arrive. How shall we establish it?

All the world is at one on this point, that disease presupposes life. In a dead body there is no disease. With death, life and disease disappear simultaneously. Tbis consideration led the older physicians to assume disease to be a self-living or even animated essence, which took its place in the body along with the vital principle. Many went so far as to define disease as a combat between two contending principles, the innate life and an intrusive foreign body. But all came back to life as a preliminary condition of disease. The view was first lost in the old Leyden school; from Boerhaave emanated the dogma, which his pupil Gaubius placed at the head of his long-used "Handbook of General Pathology," the first written on the subject: Morbus est vita prater naturam. Disease is life itself; or, to speak more correctly, it is a portion of life.

This assumption displaced the unfortunate dualism which had so long dominated medicine; or, at least, it ought to have displaced this dualism between life and disease. If, nevertheless, it has not completely done this, and if more than a century has been required to break up the still constantly existing dissonance, the reason lies in the difficulty of finding a satisfactory conception of life. And here the question must not be passed by, Where has life its special seat? Ubi sedes vita? John Hunter went back to the ancient view, already expressed in the Mosaic formula: "The life of the body is in its blood." Flourens believed that he had found the seat of life, the noud vital, in the central nervous system, in the medulla oblongata. The one, like the other, found himself obliged to institute experiments on living animals for the investigation of this difficult question. Therewith the experimental method in the more strict sense began to pass into the practice of pathologists. Vivisection became a regular aid to research.

Certainly the consideration that a knowledge of life can only be obtained on the living being was lon $y$ present. Beyond doubt it was already formed in antiquity. But it is difficult to determine with accuracy the time when it first hecame practically active. Uncertain statements only on the subject are available. Zacharias Sylvius, a physician of Rotterdam, who wrote the preface to the Dutch edition of Harvey's " Exercitationes," calls to mind the tale of Democritus, whom the Abderites rexarded as insane, recause they saw him constantly engaged in vivisection ; when however the great Hippocrates was sent for to cure him, he fully recognised the value of his proceedings, and declared that all the Abderites were lunatics, and that Democritus alone was sane. ${ }^{1}$ Probably this story has been narrated at the expense of the good Abderites; but it still shows that vivisection already "lay in the air." I will not attempt to decide whether it is true that the teachers in the Alexandrian school actually availed themselves of the permission of their king to dissect criminals. The onIy conclusion which I can derive from these tales is that researches on animals must surely have at that time been already practised. For whoever reflects on the vivisection of men must acknowledge that, especially at a time when the anatomy of animals formed the foundation of medical study, vivisection had certainly been previously done on animals. In the school of the empirics which proceeded from that of Alexandria, and in which necropsy was taught as the chief means of knowledge, experiment also appears as having a recognised claim; in the celebrated formula, which has been called the tripod of the empirics, and which served as the programme of their school, deliberately-planned experiment is expressly men-

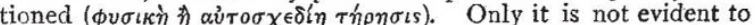
what extent this research on living animals was carried on. Hence it is also unprofitable to inquire what advantage of any kind ancient medicine derived from vivisection.

In fact, the first great and distinctive example of successful vivisection which the history of medicine knows is that of William Harvey. The foundation of the doctrine of the circulation, which in the main was experimental, has radically changed the whole direction of the thoughts of physicians.

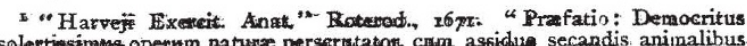
solertiasimas operum natura perserwataton, cam assidu secandis animalibus accuparetux, existimatus fuit insanus ab Abderitis; qui miserati sortem hominis advocarunt Hippocratem, ut illi medicinam faceret mentemqure alienatam restitueret. Rogatus decurrit et offendit Dem critum animalia secantem, quo spectaculo mirum in modum oblectatus, omnes Abderitas insanire pronuntiavit, solum sapere Democritum:" 
Had we this one example alone it would be sufficient to prove brilliantly the utility, yea, the indispensability, of vivisection. Never has a dogma firmly established by the tradition of centuries and every kind of authority, which in trath formed the central point of a powerful and generally acknowledged system, been ponihilated with such a headlong downfall. In complete recog. nition of the importance of such a man, Albert von Haller said that Harvey's name was the second in medicine, that of Hippocrates being the first. But it was a difficult step, to advance a new and unheard-of doctrine which interfered with science in so revolutionary a manner. Having hesitated long whether he should publish his discovery, and when he at last carried his resolution into effect, the great vivisector cried: "Utcumque sit, jam jacta est alea, spes mea in amantium veritatis et doctorum animorum candore sita" (loc. cit. p. 81).

It is certainly due, even in the present day, to the purity of a truth-loving and cultivated mind, to exonerate Harvey from the reproach of heartlessness, perhaps of brutality, of which our anti-vivisectionists are so liberal. His new knowledge had cost the lives of many animals; he started, as he himself says, "ex vivorum (experiendi causâ) dissectione, arteriarium apertione disquisitionæque multimoda." And yet that was the least thing with which he was reproached; even kings at that time were so little tender-hearted, or, I may say, with an opponent, were so brutalised, that King Charles I. found pleasure in seeing the experiments of his body-physician.

On the other hand, after Malpighi had, still in the same century, demonstrated the flow of blood in the capillaries of living animals, and after our century has added the knowledge of the existence of an actual capillary wall, the doctrine of the circulation appears so self-evident, it has so thoroughly entered into the ideas of all, that it already requires a peculiarly-trained mind to comprehend the opinion of the older physicians on the local relations of the current of the blood. Whoever goes unprepared to the study of the medical classics, falls from one misunderstanding into another. The ideas of the nature of local processes are entirely changed, and yet the circulation, the capillary certainly more than that of the larger vessels, stands in the foreground of pathological interest almost more than in truth it should. The widely comprehensive doctrine of inflammation and new growth, within which nearly the greater part of practical cases occur, was founded on experiments on the capillary circulation; not less so was the doctrine of the cure of local diseased processes of most varied kinds.

Even the worst opponents of vivisection recognise Harvey's services. But, say they, since then, nothing more of importance has been accomplished by vivisection. They do not know that it is precisely that department of the doctrine of the process of the circulation which embraces the vital properties of the organs of circulation, which is entirely unmentioned by Harvey.

On what does the activity of the heart depend? What influence do the vessels exert on the propulsion and distribution of the blood? What share falls to the arteries, what to the veins, what to the capillaries? All these questions are of the highest practical importance, and none of them can be investigated otherwise than by experiments on animals. But Harvey could not attack these questions, because in his time minute anatomy was not yet developed. Who knew anything of the nerves of the heart, or of the vessels? Who had any notion as to the participation in the manifestations of the action of the heart and blood-vessels, on the part of the nerves, which supply the parietal structures, especially the fine muscles?

An interval of two centuries again intervened before Edward Weber, by experiment on the vagus nerve in a living animal, first revealed the mystery of the innervation of the heart; and this, again, in a quite unexpected and unprececlented manner and before our now so much abused friend Claude Bernard likewise showed on a living animal the influence of the sympathetic nerve on the vessels of the head and neck.

Now for the first time, and through numerous other experiments which have tended to this end, we understand the circulation in its special characters. The pulse, that so highly treasured object of the old symptomatology, allows itself to be interpreted. It is to us no longer the sign of this or that disease, but the sign of the existence or non-existence of certain activities, of strength or weakness, of irritation or relaxation of certain tissues. Now for the first time we can understand in its individual peculiarities the action of the heart itself and the operation on it of certain substances-e.g. cardiac poisons; and it is not almost alone the department of diseases of the valves, to which alone, and with a scorn that cannot be rightly understood, the anti-vivisectors point on account of their incurability, but also the department of febrile diseases, which we are in a position to survey as well with regard to their symptoms as to their nature and their results.

The length of the interval of time between Harvey and the more recent experimenters on the innervation of the vascular apparatus is explained by the circumstance that in that intermediate time two entirely new studies had to be created, to both of which the discovery of the circulation was an impulse and a preliminary condition. I mean physiology and general pathology ; thus, indeed, both these studies, which are to be regarded as the chief support of the experimental method, and which it was originally the custom to comprise under the name of "Institutiones Medicæ." Hermann Boerhaave had, in his professorship, combined them, and, indeed, had even united them with practical medicine; under his pupils the division of labour commenced, and the formal separation of the studies. Haller was the special creator of physiology. His experiments went first in the direction of exploring the vital properties of individual parts of the body, of single tissues, as wonld now be said. Among these properties, following the distinguished Glisson, a man, it seems to me, not even now sufficiently honoured in his country, he assigned a prominent place to irritability. It would lead me too far if $I$ in this place desired to attempt to show forth individually these memorable researches, the comprehension of which was rendered extremely difficult by the then not yet sufficiently complete explanation of the motions "irritability" and "contractility." For our purpose it is sufficient to point out that here for the first time nerve and muscle, the two most highly developed and thereby most energetic portions of the animal body, were made the subjects of experiment with regard to their special forms of activity. Contraction and sensibility appear as the special signs of living activity. Therewith the question of the basis of living activity was so nearly approached that Gaubius, who at the same time laid the foundations of general pathology, indicated the vital force as the source of contraction, without going further. ${ }^{x}$

From these beginnings was developed, at first in a very obscure and equally unprofitable manner, especially clouded by speculative vitalism, the doctrine of life in its modern form. It has required much longer labours, mostly experimental, to arrive at a great and practical result in spite of all deviations. From the conception of irritability, originally created by Glisson, that of contractility bas gradually become separate : and the contrast in which Haller placed irritability and sensibility with regard to each other has been dissolved, by the fact that contractility and sensibility are regarded as two special forms of expression of life connected with various elements, and are subordinated to irritability as the general expression. In this sense, irritability and vitality are nearly identical. Both are properties of tissue, and as such directly or indirectly accessible to treatment and experiment.

In fact, experimentation is now rather directed to the tissue itself. Galvani's discovery of electric contractions, the labours of Alexander von Humboldt on irritated muscle and nerve-fibre, and many other contemporaneous researches, afford evidence of the changed direction in which the new biology laboured. More and more sank down the mysticism of the spirits of life and of disease, the speculation as to an individual vital force; and from generation to generation medicine assumed more and more the character of a real natural science. The obscurity which had dominated especially the nervous system, disappeared under the common labours of anatomists and experimenters; and especially since Charles Bell taught the difference of the nerves hitherto considered as similar in nature, and thereby opened the road to research on the special importance and power of the single divisions of the central nervous system, one work after another has appeared, which has diffused new light on this difficult and complicated subject. It is impossible to go through all these works on this occasion, and it would be superfluous in an assembly of such accomplished men, many of whom have them. selves laboured in this glorious work.

I will now only briefly point out that among these labours a constantly clearer and more triumphant idea has advanced, which in its beginnings reaches far back into past time-namely, the idea of the proper life (vita propria) of the tissues. Every new form of experiment which is devised renders new parts accessible

${ }^{x}$ Gaubius, "Institut. Path. Med.,",p. 7x. "Vis vitalis solidi est, qua illud ad contactum irritamenti se contrahit." 
to scientific examination, and with each step in advance we become more clearly convinced that life, regarded as a great unit in the established sense, is a pure fiction, arising from the observation that in the hierarchical organisation of the human body certain organs attain so elaborate a structure, and therewith so great importance, that they with complete right merit the name of vital organs. And as among these organs the medulla ob. longata possesses the greatest importance, it is easily comprehensible that the idea should arise that it might really be the seat of life. But we know now that life is a collective functional action of all parts of the higher or vital, as well as of the lower and less important; and that there is no one seat of life, but that every true elementary part, especially every cell, is a seat of life. In biological research, also, as well as in pathological, we have arrived at a multiplication of foci. Of course the number of vital foci is much greater than that of foci of disease can ever be ; and hence disease and life, or to speak more accurately, diseased and healthy life, can very well coexist in the same organism; always, however, so that disease signifies a reduction, a minus of healthy life. By this research we have even rediscovered the long-lost essence of disease, not indeed in a spiritualistic form, but as a quite material ens, a genuine incarnate thing-the altered cell.

Has all now produced advantage? Was it worth the trouble to inflict pain on so many animals? to kill so many animals? Is there a really justifiable claim for allowing the experimental method to proceed still further? We can answer all these questions confidently in the affirmative. Not every experiment on animals has results as great as that of Galvani, results which have not merely led to a new and effective method of treating disease-electrotherapy; which have not only disclosed a large new territory of vital processes, but have supplied the first preliminary condition for an incalculable number of the most important technical arrangements, the knowledge of the natural course of events. But galvanism might yet appear to limited and timid heads as an instructive and refreshing play, for the reason that not every result of true observation of nature is usually brought forward at once, and that nevertheless it may be of the highest practical value. The cellular theory and the proof of the vita propria seu cellularis are in themselves very abstruse things, and no one can cure patients by their means without understanding something further. And yet they have become the foundation, yea, in a certain measure the security, for localising therapeutics, and they will surely become more so from day to day, when first materia medica in its wider extent shall have gone on the way which toxicology has already for a long time followed in a manner so rich in results.

How then can a great result to the science of healing be expected, if research in animals be cut off? For a long time no remedy has been more rapidly recognised, or more extensively used, than chloral, the effects of which were discovered and established experimentally by Herr $O$. Liebreich in my laboratory. How would it have been possible to know how to ascertain those effects without experiments on animals? The animals' friends say to us, "Then try the new medicine on yourselves!" They refer us to the provings of medicines by the homœopaths. But, quite independently of the fact that the provings of the homoeopaths have not taught us to recognise one single new remedy which can be compared even at a distance with chloral, and that these provings, even in regard to already known remedies, do not in the least correspond to scientific investigations ; that thus they cannot be altogether regarded as an original example-one will yet not be able to earnestly desire that very different, possibly poisonous bodies, should be made the subject of self-experimentation by physicians or other men. This kind of morality, which forbids experiments on animals and counsels experiments on one's own life or on sick men, misses, in fact, the first foundations of intelligent examination.

The proof of the great importance of hygiene and prophylaxis is rather superfluous. If any class of men has been active in this direction it is surely medical men. Never has there been a want of zealous hygienists among them; and when a great problem of prophylaxis was to be solved, one might be sure of finding medical men engaged in the work. We are so accustomed to this obligation that we always regard hygiene and prophylaxis as belonging to medicine, and to no other science. But it is empty talk when it is said that prophylaxis will render therapeutics-yea, even in a certain degree, medicine-superfluous, The arrangement of this imperfect world is such that there surely will be sick as long as men exist; and we are not afraid because of the threat that there will be no further need of us. Not even through the assistance of hygiene will people be able to do without us; and still less withont experiment on animals. Will even the hygienists be condemned to test the various "causes" cold and warmth, dryness and moisture, dust and noxious gases, micrococci and bacteria, on their own persons, in order that they may from such self-observations determine their effects, and formulate laws? Intelligent Governments will comprehend that it would be an act of madness to sacrifice human life, merely because it occurs to a small number of persons that it is criminal to sacrifice the lives of animals. Medical men are already more exposed in epidemics of all kinds, in the performance of their duties in hospitals, in the country, in their nocturnal visits to the sick, in operations and necropsies, than any other class of the community as a rule; and it requires all the blindness of the animal fanatics to require also of them that they should test on their own bodies the remedial, or poisonous, or indifferent action of unknown substances, or that they should determine the limit of permissible doses by observations made on themselves.

In the name of humanity, of morality, of religion, the suppression of experiment on animals is demanded. For, in fact, it is not merely vivisection that is in question, but experiment on animals; that is, the experimental method in general. When the term vivisection is used it is made to include in like manner all painful actions in which there is no cutting ; indeed, to prevent any misconception, not only physiological, but also pathological and pharmacological, experiments, are expressly included. The criterion is pain. Everything by which, in the way of experiment, pain is inflicted on an animal is torture of animals, and so far immoral, and contrary to religion. With this definition of torture of animals it might be possible to arrive at exceptional results by applying it to other callings or men. The dogfanciers, who in the rearing of their dogs often use, or cause to be used, methods full of torture and painful chastisement, would readily come into great danger. The improvement of horses for certain purposes would have to be entirely put down. A great part of our domestic animals would have to remain untrained, so that pain might be spared to them. We should perhaps arrive at conditions similar to those produced by the wild dogs in Turkey.

Individual anti-vivisectors are at least so far consistent that they would see the slaughter of animals also forbidden. From the vegetarian standpoint, the opposition gains a kind of systematic aspect. Thus Herr von Seefeld ${ }^{l}$ demands a vegetable diet and the prohibition of vivisectors; but as he, as a vegetarian, has no need of flesh, he is strongly inclined to make still further concessions. Thus he rejects hunting for the purpose of pleasure, but cannot altogether dispense with it as a means of defending life. Others go still further, and sacrifice also war. The principle can scarcely be denied, that death is worse than torture. There could scarcely be a criminal code, which punishes the premeditated killing of a man less severely than the torture of a man. Not without reason is it alleged that a man who still remains alive after his misdeeds may recover and attain to a complete or entire enjoyment of life. Grounds of mitigation in cases of murder and manslaughter are allowed also to men; but, as a foundation, the extremest injury which can be inflicted on man is always and every where the most severely punished.

As regards animals, the anti-vivisectors, on the contrary, consider torture to be worse than death. Although they reject every torturing or painful method of death, even for cattle, they without the slightest consideration cause animals, even highly organised ones, to be slaughtered or killed, not only for eating, but also for other purely subjective reasons. They go, indeed, so far as to demand that an animal which has survived vivisection shall be killed, although it might possibly still enjoy a long and happy life. Is there any logic in this, or any morality? How ? May we have the right to kill an animal on any ground of public utility, to eat its flesh, to sell its skin, to pound its bones to manure for the field? and are we not to have the right of subjecting it to scientific research, which we institute on entirely ideal grounds, or on the grounds of the public weal, in which we even perhaps run the risk of becoming diseased? It will be difficult to assume that we institute researches on glanders or splenic fever for pleasure, or to pass away time, or without knowledge of the great danger of inoculation. Whoever allows himself the right to kill animals, has no right to forbid physiI Alfred von Seefeld. "Altes und Neues über die vegetarianische Lebens. weise." (Hanover, 1880.) 
cians to vivisect animals for experimental purposes, or to undertake painful operations of any other kind.

Of course we cannot desire that the misuse of this right should escape punishment. For it is with such an abuse, not with the production of pain, that torture of animals first comes into operation. Were every production of pain in itself an act of torture, punishment ought to be inflisted on a veterinary surgeon when he operates on a sick herse for the purpose of curing it. Culpable torture of animals lies before us, when pain is inflicted on an animal in a useless manner, and without purpose. Hence nothing can be said against the view that every experimenter should be subject to official inspection; but surely this does not require a society for the protection of animals. He who has a greater interest in domestic animals than in science, that is, in the knowledge of truth, is not qualified to be an official controller of scientific affairs. To what would it lead, if an experimenter, who had commenced his experiment in good faith, had perhaps o answer to some layman during the experiment, or to a magistrate afterwards, the charge that be had not selected some other method, or some other instruments, or perhaps some other experiment?

No: here is no question of objective right. So long as perfect liberty is left to every possessor of animals to kill his animals, be they wild or tame, at any time, and according to his own juelg ment, so long must it also be permitted that, for scientific ends, and thus on purely internal grounds, experiments should be made on living animals. But the necessity of such experiments can naturally only be decided by the inquirer himself; as to the choice of place, time, the admission of strangers, he may be required to communicate with the inspector; but the carrying out of the experiment must remain in his own hands. So we understand the expression of the freedom of science.

What is objected to us is, that it is the outraged feelings of the posses-or of horses, pet dogs, and parlour cats that excite him to the belief that the same thing may happen to his beloved animals as to the animals in the learned institute. We can sympathise with him. We would force no one to deliver to us his favourites, not would we steal them. 'Were either of the two to o:cur, probably in every country the intervention of the masistrate would be called on with effect. But we also require that the disposal of the life and maintenance of those animal, which have come into our possession in a legitimate way, shoul: 1 not be lessened to us, and that we should not be con sidered or declared to be à priori rough, void of moral feeling, and basbari-uns standing almost on the threshold of crime. The evidence that moral earnestness is failing in modern medical circles is nowhere afforded. The seproach that Christianity is imperilled by vivisection is worthy of Abdera. The assertion that the medical youth are inevitably " brutalised" by dissection and vivi-ection.is, as usual, snatched from the air; as it is also a calumny that the vivisecting teachers have suffered injury to their morality

At least however there is no ground to fear for science itself, To it is applicable what Bacon said of the sun: "Palatia et cloacas ingreditur, neque tamen polluitur."

\section{SOCIETIES AND ACADEMIES \\ PARIS}

Academy of Sciences, August 1.-M. Jamin in the chair.The following papers were read:-On the formation of tails of comets (-econd note), by M. Faye. Herschel, Arago, Delaunay, and other astronomers did not thoroughly study the tails of comets, but Newton had already given a quite sufficient explanation of the phenomena. The tail is nothing else-he maintained -than the result of a continual emission of molecules from the head of the comet. It is very much like the tail of smoke emitted by a running locomotive, its outer end being lost in space, and the inner one continually receiving a new supply of molecules. M. Rache, who has made the necessary calculations, taking account of the repulsive force M. Faye advocates, has worked ont all those shapes of tails which we witness in reality.-On the equivalenee of quadratic forms, by M. Jordan.-On a modification of the electric lamp, by M. Jamin, being the re ult of observations on the electric light in vacuum, and in closed vessels containing various gases.-On the perchloric acids, by M. Berthelot - On the travels of Moncatch-Apé, by M. Quatrefages. This American Indian undertook a journey to the north-western coasts of America at the beginning of last cen'tury, in search of the origin of his race; whilst on this coast he learned and witnessed that it was visited every year by white men with long black beards, and M. Quatrefages proves that these men were originally from the Loo Choo islands.- On the first meteorological, topographical, and hydrographical obserwations at the future Panama canal, by M. de Lesseps. Several maps of the coast are prepared, and a meteorological station is opened at Colon.-On the application of electromotive power and of M. 'Planté's secondary piles to the direction of aëro:tats, by M. Tissandier. In an aërostat which has a volume of 2200 litres, $3.50 \mathrm{~m}$. long, with a diameter of $\mathrm{r} \cdot 30 \mathrm{~m}$., and can raise a weight of 2 kilogrammes, having a Siemens machine which weighs 220 grammes, and a secondary couple of r300 grammes, the propulsory helix makes six and a half revolutions per second, and the balloon acquires a speed of I metre per second for forty minutes. The small Siemens machine, with three elements, produces the work of I kilogrammetre, - The elements of comet $c$ of I88 I (Schäberle), by M. Bigourdan, as deduced from observations at Vienna on July 18 , and at Paris on July 23 and 28 . Its brightness, which is still increasing, will be on August 23 seventeen times as much as it was on July i8. -Spectroscopical observations on the comets $b$ and $c$, 1881, hy MM. Thollon and Tacchini.-On the lengths of spectral bands given by compounds of carbon, by M. Thollon.-On the constitution of comets, by M. Prazmowski.-On the theory of trilinear forms, by M. Le Paige.-On the influence of pressure on dissocia. tion, by M. Lemoine.-On the heat of formation of explosives, by MM. Sarrau and Vieille.-On oxycyanides of lead, cadmium, and mercury, by M. Joannis. - On the heat of combustion of heptane and of hexahydrotoluene, by M. Louguinine.-Third note on the magnesia industry, by M. Schlösing.- A contribution to the study of the tran mission of tuberculosis, by $M$. Toussaint. The juices of animals which have had tuberculosis transmit the disease with very great ease, even when submitted to a high temperature, but especially when employed uncooked. - On the injection of the virus of rabies into the circulation, by M. Galtier. It seem: to prevent infection.-On hemeralopia and on the functions of the visual purple, by $M$. Parinaud.-On the applications of electromotors, by $\mathrm{M}$. Trouvé.

\section{VIENNA}

Imperial Academy of Sciences, July 21.-L. T. Fitzinger in the chair.-A. Rollett, on the derived albumins noted as acidalbumins and alkaline albuminates. - Dr. Stur, on 'the Silurian flora of the $\mathrm{H}-h_{1}$ stratum in Bohemia.- S. Lustgarten, on an ethyl nitrate formed by the action of nitric acid on glycogen. Ernst Lecher, on the spectral distribution of ratliant heat.-Pr. T. Kessel, on the function of the external ear in relation to the space-perception. - On the difference of intensity of a linear-produced sound in different directions, by the same.-F. Fossek, on the products of condensation of isobutyl aldehyde. $-\mathrm{Zd}$. $\mathrm{H}$. Skraup, on quinine and quinidine.-Note on some quinirie com. pounds, by the same.-Prof. Freund, on the formation and preparation of trimethene alcohol from glycerine.-Preliminary note on trimethene, by the same.- $\mathrm{H}$. Weidel, on a compound isomeric to $a$-sulphocinchoninic acid. - G. Goldschmidt, on monoand dinitropyrene and amidopyrene. $-\mathrm{E}$. Wei-s, a communication on the third comet of the year I88I (I88I $c$ ), discovered by Schäberle at Aun Arbor (Michigan).-T. Woehner, report on his observations of the earthquake phenomena in Croatia in the year 1880 .

\section{CONTENTS}

PAgr

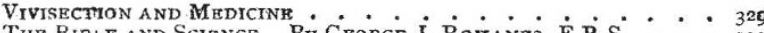
The Bible and Science. By George J. Ramangs, E.R.S. . . . 332 ThS ro HR EDITOR :-

Though -Reading.-Rev. Georgs Henslow . . . . . . . . 335
A Gun-Signal Recorder-A. G. P.

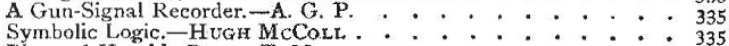

Bisected Humble-Bees.-T.MASHEDER $0: 0: 335$

A New Meter for Electric Currents. - JohN T. SpRAGUE : 335 A Popular Account of Chamalegons, II. BySt. George Mivatit, F.R.S.

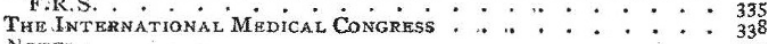

Notes. . . . . . . . . . 339

ur Astronomical Column :-

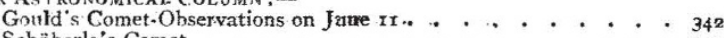

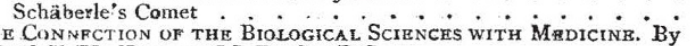
Pruf. T. H. HUXLEY, LL.D., Sec R.S. . . . . . M Prof. Rudol ON THE VALUE OF PATHOLGGICAL EXPERIMAN TS. By Prof. RUdolF Virohow, M.P.

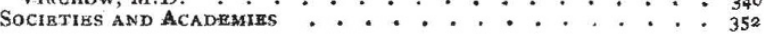

